\title{
PERAN ETHYLANE DALAM PERTUMBUHAN DAN PENGEMBANGAN TANAMAN
}

\section{THE ROLE OF ETHYLANE IN PLANT GROWTH AND DEVELOPMENT}

\section{Handri Rama Pradani}

Jurusan Teknik Kimia, Universitas Negeri Semarang, Semarang,- Indonesia email: handriramal23@gmail.com

\begin{abstract}
Abstrak
Etilena merupakan suatu gas pertumbuhan yang telibat dalam beragam proses seluler, perkembangan dan proses terkait stress pada tanaman. Sejumlah peran yang dimainkan oleh etilena contohnya penentuan jenis kelamin bunga, induksi bunga, pemanjangan tunas dan pengurangan daun. Kemajuan terbaru tentang pemahaman mekanisme molekuler yang mendukung pasca-penyerbukan pada proses layunya bunga anggrek telah dilakukan pengujian. Studi ini menunjukkan bahwa proses bunga anggrek menjadi layu pasca penyerbukan melibatkan sensitivitas awal terhadap kadar etilena endogen yang berperan menggerakan proses dimana etilena secara autokatalitik menginduksi sintesisnya sendiri dalam putik. Konsep yang diambil dari proses ini kemudian diterapkan pada episermis akar arabidopis dimana etilena mempunyai peran pentig dalam perkembangan rambut akar. Memahami konsep molekuler tentang peran etilena dalam model ini akan memberikan manfaat yang berguna untuk mengetahui bagian yangh dimainkan oleh etilena dalam beragam proses yang melibatkan faktor pertumbuhan.
\end{abstract}

Kata kunci :

Etilen,

pertumbuhan,

perkembangan .

Keywords:

Etilen,

pertumbuhan, perkembangan.

\begin{abstract}
Ethylene is a growth gas that is involved in a variety of cellular processes, development and stress related processes in plants. Playing the role played by ethylene for example choosing the type of flower, flower induction, elongation of shoots and leaf recovery. Recent advances in understanding the molecular transition that supports post-pollination in the process of withering orchids have been tested. This study shows that the process of orchid flowers withering after pollination requires initial sensitivity to endogenous ethylene levels that support the movement process while ethylene automatically changes its own synthesis in the pistil. The concept taken from this process is then applied to the epidermis of arabidopic roots while ethylene has a significant role in the development of root hairs. Understanding the molecular concept of the role of ethylene in this model will provide useful benefits for understanding the part that ethylene plays in various processes that require growth factors.
\end{abstract}

\section{PENDAHULUAN}

Perkembangan tanaman melibatkan kelahiran progresif dan kematian bagian interasinya seperti akar, daun, pucuk, bunga dan kuncup [I]. Analisa tentang perkembangan bentuk pohon, kehidupan tunas dapat diperiksa dengan menghitung jumlah bagian yang menentukan umur dan nasib terakhir tanamn [I]. Nasib kuncup misalnya, sangat ditentukan oleh posisi mereka dipohon. Tunas yang hidup disekitar induknya memliki peluang lebih besar untuk bertahan hidup, pada akhirnya berkembang sebagai tunas yang panjang atau berkembang[I][2]. Tunas yang posisinya lebih jauh dari induknya relative tidak aktif atau lebih senderung mati. Banyak factor yang mempengaruhi dalam pola pengembangan ini, jelas bahwa etilena memainkan pran kunci dalam proses ini. Peran yang dimainkan oleh etilena dalam pertumbuhan dan perkembangan tanaman akan dijelaskan menggunakan contoh- contoh dari banyak spesies angiospermae dan gymnospermae [I]. Beberapa proses penting dalam pertumbuhan dan perkembangan tanaman seperti penebalan sekunder, reaksi pembentukan kayu, perkembangan bunga, penentuan jenis kelamin, penuaan bunga, pengurangan daun, pemanjangan tunas, dan diferenisasi sel.

\section{Biosintesis etilen dan sinyal terinduksi}

Etilena adalah gas pertumbuhan pada bibit 
Handri Rama Pradani. Peran Ethylane Dalam Pertumbuhan Dan Pengembangan Tanaman.

\section{kacang polong (Neljubov, 190I). Etilen}

berasal dari asam amino dan metonin. Metionin diubah menjadi asam I- aminocyclopropane-Ikarboksilat (ACC), ACC dikonversi menjadi etilen oleh ACC oxidase atau ACO [I]. ACC larut dalam air dan telah terbukti bergerak melalui apoplast pada jarak yang sangat jauh (dari akar ke pucuk) ditanaman tomat telah terbukti bergerak dari permukaan stigma menuju kelopak bunga dalam berbagai spesies [I]. Etilen 14 kali lebih larut dalam lipid seperti dalam air dan zat teterlarut lainnya yang dalam fase cair [I]. Bagian genetic dari jalur terinduksinya sinyal etilen telah memberikan pandangan yang kuat ke dalam mekanisme molecular yang menopang respon etilen dan telah menyediakan banyak alat bagi para ahli untuk mengembangkan dan memeriksa secara spesifik tentang pengembangan tanaman [I][4]. Penapisan Populasi muatan untuk tanaman yang menunjukkan respon terhadap etilen abnormal yang menyebabkan terinduksinya sinyaal etilen pada identifikasi sejumlah gen (Bleecker etl, 1988).

\section{Peran Kunci Etilen}

Bentuk pohon

Setelah berkecambah, meristem pucuk yang diletakan dalam embrio yang sedang berkembang menghasilkan system pucuk yang terdiri dari unitunit berluang, daun, simpul, ruas dan tunas akdila. Dimana pola unit-unit konstruksi ini disatukan dalam satu spesies[I][3]. Jumlah dan status unit yang bertahan di tanaman berumur panjang sangat ditentukan oleh factor lingkungan seperti cahaya, ketersediaan air, tekanan fisik dan lainnya. Tekanan fisik merupakan factor penting dalam penentuan bentuk tanaman, contoh yang paling mencolok dari pengaruh tekanan mekanis tidak hanya pada perawakan tumbuhan tetapi dari seluruh jenis vegetasi. Tinggi badan tanaman ditentukan oleh kedekatan dengan puncak, tanaman di puncak memiliki batang relative tebal dan ranting yang lebih halus sedangkan tanaman yang tumbuh didaerah yang kurang terbuka relatif lebih tinggi dengan ranting yang lebih tebal [I][6]. Dalam serangkaian eksperimen klasik tentang pengembangan kayu kompresi di pinus strobus menyoroti peran regulative kayu reaksi dalam mennaggapi stimulasi fisik [5]. Kayu Reaksi adalah jenis kayu khusus yang dibuat oleh tanaman sebagai respons terhadap tekanan fisik [8]. Sejumlah percobaan telah melibatkan etilen dalam respon pohon terhadap tekanan fisik. Induksi etilena sebagai respon terhadap tekanan fisik pada bibit kacang [7].

Perubahan orfologi

yang

berpengaruh pada penurunan tinggi dan peningkatan ketebalan pada pohon diperlukan pemeriksaan pada poduksi etilen pada cabang pinus, persik dan apel [9]. Percobaan itu mirip dengan yang dilakukan Sinnott karena cabang-cabangnya ditekuk dan diikat sedemikian rupa sehingga kelengkungan 90 ० diperoleh pada kayu berumur 4 tahun. Tiga hari setelah stres dihilangkan, kadar etilen meningkat 2-3 kali lipat yang melibatkan etilen sebagai respons terhadap stres mekanik [10]. Dalam penyelidikan lebih lanjut, ACC diisolasi dari jaringan kambial yang dikumpulkan dari bagian bawah cabang Pinus contorta yang tumbuh secara plagiotropis di mana bentuk kayu tekan, sementara tidak ada yang terdeteksi dalam kambium dari sisi atas cabang di mana tidak ada kayu tekan yang berkembang [I][I I].

$\begin{array}{ccc}\text { Gangguan } & \text { mekanis bidang } & \text { dan } \\ \text { greenhousegrown } & \text { Abies } & \text { fraseri }\end{array}$ menghasilkan peningkatan ketebalan dan penurunan tinggi dibandingkan dengan tanaman kontrol [I][I2]. Peningkatan ketebalan hasil dari peningkatan aktivitas kambial dan perkembangan trakeid ke arah perturbasi. Penurunan tinggi mungkin disebabkan oleh penurunan panjang trakeid yang berkembang sebagai akibat dari gangguan [13]. Sementara pembentukan tunas panjang dan pendek merupakan faktor utama dalam pengembangan bentuk pohon birch, demikian juga hilangnya (penyisihan) dari struktur-struktur ini [I].

\section{Perkembangan Bunga}

Perkembangan bunga dari subset tunas musim dingin di brich merupakan faktor penting dalam menentukan bentuk pohon, karena tunas tersebut sebagai indikator keadaan bunga dan tidak memberi kontribusi bagi tubuh tanaman di masa depan. Sementara etilen belum terlibat dalam pengembangan bunga di birch, gas ini digunakan secara luas sebagai penggerak perkembangan bunga di sejumlah spesies yang memiliki kepentingan hortikultura. Contoh yang paling menonjol adalah penggunaan etilen untuk induksi pembungaan dalam nanas [14].

Induksi tergantung adanya keberadaan daun 
pada tunas, tidak akan ada induksi apabila semua daun dihilangkan [I]. Efek etilena pada Aechema Victoriana telah terbukti bergantung pada ukuran tanaman. Tanaman yang memiliki ukuran kurang dari $22 \mathrm{~g}$ gagal berbunga pada perlakuan ACC sementara tanaman yang memiliki ukuran $23 \mathrm{~g}$ keatas lebih merespon. Semakin besar tanaman pada saat perawatan, semakin besar bunga yang dihasilkan [I].

Etilena adalah penginduksi kuat dari pembungaan dalam geofit, tanaman dengan organ perennating bawah tanah, seperti umbi-umbian [14]. Meskipun penggunaan asap sebagai penginduksi kuat bunga di Iris telah menjadi praktik tradisional dalam berbagai budaya selama ratusan tahun, sedikit yang diketahui tentang mekanisme yang terlibat.

Penentuan Jenis kelamin

Setelah meristem telah berkomitmen untuk membentuk bunga di pohon birch, jenis kelaminnya kemudian ditentukan oleh posisinya di pohon [I]. Perbungaan jantan (catkins) berkembang pada akhir musim tanam pada tunas panjang dan perbungaan betina berkembang di musim semi dengan tunas pendek. Sementara dasar fisiologis penentuan jenis kelamin bunga dalam birch tidak dipahami, banyak yang diketahui tentang peran penentuan jenis kelamin bunga yang diatur etilen dalam cucurbits (mentimun dan melon).

Banyak varietas hortikultura monoecious (bunga jantan dan betina diproduksi di tanaman yang sama), sementara yang lain ginekomis (bunga betina dan hermafrodit diproduksi di tanaman yang sama). Tanaman ginekomik yang tumbuh di bawah kondisi lingkungan yang mendorong perkembangan wanita menghasilkan lebih banyak etilen daripada tanaman monoekus, yang mengindikasikan bahwa etilen dapat dikaitkan dengan feminisasi bunga [I5].

Penghapusan gas endogen (termasuk etilen) dengan menumbuhkan semua tanaman betina ini dalam kondisi hipobarik, menghasilkan pembentukan bunga hermafrodit, konsisten dengan peran feminisasi untuk etilen endogen dalam pengembangan bunga betina $[\mathrm{I}][3]$. Konsisten dengan peran feminisasi etilen dalam perkembangan bunga adalah pengamatan bahwa inhibitor biosintesis etilen menghasilkan pembentukan bunga sempurna atau jantan, tergantung pada spesies dan latar belakang genetik [4]. Sementara peran etilen dalam feminisasi bunga telah jelas ditunjukkan, faktor pertumbuhan lain, asam giberelat (GA) dikenal untuk mempromosikan

pengembangan bunga jantan. Peran GA dalam penentuan jenis kelamin pada jagung juga telah ditunjukkan secara genetik [4] Sebuah penelitian baru yang telah dilakukan pada mentimu mnunjukkan bahwa etilen digunakkan untuk menjadikan jenis kelamin tanamn menjadi betina dan kelamin menghambat kejantanan, sedangkan GA menentukan agar memiliki kelamin jantan dan menghambat keperempuan [14]

Basis Sel Dari Perubahan Etilen Dalam Bentuk: Etilen, Pemanjangan Sel, Mikrotubulus, Dan Mikrofibril

Perawatan pada jaringan dan organ tanaman dengan etilena yang mengikat menghasilkan perubahan yang signifikan pada ekspansi sel yang tumbuh. Sel-sel pada akarsebagian besar mengalami ekspansi yang sejajar dengan sumbu panjang akar. Sel pendek dan luas secara radial dari banyak akar yang tumbuh di tanah mungkin juga dihasilkan dari etilena akibat adanya impedansi mekanik. Perubahan serupa juga terjadi pada tracheid yang berdiferensiasi pada kayu reaksi sebagai respon terhadap stimulasi pada [3]. Mikrofibril selulosa di lapisan dalam dinding sel memanjang umumnya tersusun tegak lurus terhadap sumbu panjang sel. Hal semacam itu dianggap menguntungkan secara mekanis karena tegangan transversal dalam sebuah silinder adalah dua kali tegangan aksial [4] Mikrotubulus dalam sel memanjang mencerminkan keselarasan terhadap mikrofibril. Perubahan dimensi

pertumbuhan yang terkait dengan perlakuan etilen terhadap mikrofibril selulosa yang baru lahir pada lapisan dinding bagian dalam dan sitoplasma kortikal pada mikrotubulus

[I] Selain itu, pengobatan GA sel memanjang memiliki efek sebaliknya: sel memanjang dan mikrofibril dan mikrotubulus menjadi relatif lebih berorientasi transversal [I].

Pemanjangan batang

Tunas pada pohon brich dapat dapat membentuk tunas yang panjang atau pendek tergantung pada posisi tunas di pohon [I]. Tunas yang dekat dengan induknya terpapar cahaya yangtinggi dan cenderun membentuk tunas yang panjang akibat aktivitas fotosintesis yang tinggi. Ekstensi pucuk pada pohon brich yang sedang berkembang sangat erat dengan kebutuhan cahaya. Studi awal tentang Callitriche 
Handri Rama Pradani. Peran Ethylane Dalam Pertumbuhan Dan Pengembangan Tanaman.

menunjukkan bahwa akumulasi etilen pada batang tanaman yang terndam mempunyai peran penting dalam pemanjanggan tunas [5].Pertumbuhan batang bamboo yang diinduksi dalam air hasil dari sintesis ACC untuk mengantisipasi penurunan tingkat $\mathrm{O} 2 \mathrm{di}$ ruang antar sle tanaman yang tergenang menghasilkan peningkatan orde dua dalam akumulasi etilen dalam batang lacunae [7].

Perawatan air beras dengan tambahan etilena dapat menginduksi stimulasi pertumbuhan seperti submergence [8]. Pemeriksaan peran GA menunjukkan bahwa etilena dapat bertindak dengan meningkatkan aktivitas GA endogen dan dengan demikian merangsang pertumbuhan [13].

Efek utama dari perendaman dalam air beras untuk meningkatkan jumlah sel yang dihasilkan dari penurunan waktu siklus dari sel tersebut dalam sel batang [I]. Pemanjangan pada meristem meningkat luasnya hingga tiga kali lipat.

Mekanisme molekuler yang menopang pembentukan bentuk tanaman oleh etilena

Pemahaman mekanistik layu yang disebabkan penyerbukan di anggrek, Phalaenopsis, berdasarkan analisis molekuler dari proses ini, saat ini sedang muncul. Model ini melibatkan regulasi perkembangan biosintesis etilen dan sensitivitas [9]. Dalam contoh kedua, sebagian besar studi genetik pengembangan epidermis akar di Arabidopsis dijelaskan [I][6]. Pengaturan sel dalam system ini dikendalikan oleh biosintesi dan sensitivitas etilen. sistem tersebut memberikan mekanistik tentang peran etilen dalam pengembangan bentuk tanaman dan kemajuan terbaru pemahaman kita tentang dasar molekuler dari pematangan buah tomat dan peran etilen dalam peran respon terhadap luka akan menggambarkan beragamnya peran etilen pada tanaman.

Perubahan sensitivitas etilen dan ACC mengatur penuaan yang disebabkan penyerbukan pada anggrek

Penyerbukan mewakili aliran kehidupan pada banyak bunga. pada banyak spesies, penyerbukan menghasilkan kelayuan atau pelepasan total segmen perianth. banyak kelopak bunga petunia dan anggrek layu [10]. etilen memainkan peran inti dalam proses yang menyebabkan absorbs dan kellayuan pada perianth. sebuah model telah diusulkan untuk mekanisme layu pasca- penyerbukan di anggrek, Phalaenopsis. Model ini menunjukkan bahwa penyerbukan menginduksi sensitivitas etilen dalam sel-sel gynoecium yang kemudian merespon kadar etilen endogen (rendah), sehingga mengaktifkan gen-gen biosintesis etilen dalam pola yang ditentukan yang menghasilkan akhirnya layu bunga [I]. Langkah pertama di jalur setelah penyerbukan adalah induksi sensitivitas etilen dalam bunga. Ini diperiksa dengan memaparkan bunga yang diserbuki ke etilena pada waktu yang berbeda setelah penyerbukan [I].

Ditemukan bahwa sensitivitas meningkat setelah 4 jam, naik ke maksimum antara 8 jam dan 12 jam setelah penyerbukan. Bahwa perubahan dalam sensitivitas ini tidak tergantung pada kadar etilen endogen diilustrasikan dengan mengekspos bunga yang diserbuki menjadi etilen di hadapan asam amino-oksiasetat, yang menghambat biosintesis etilen [9]. Karena banyak penelitian telah mengindikasikan bahwa $\mathrm{Ca} 2$

+ memainkan peran penting dalam pro- mediated ethylene. sensitivitas etilen diperiksa pada bunga yang tidak dicabut setelah perawatan dengan I mM $\mathrm{Ca} 2+$ dan ionofor $\mathrm{Ca} 2+\mathrm{A} 23187$ [9]. Hasil ini menunjukkan bahwa induksi sensitivitas tidak tergantung pada etilen itu sendiri dan peningkatan sensitivitas membuat sel-sel pada bunga sensitif terhadap endogen, kadar etilen rendah yang ada dalam jaringan bunga. Ini menghasilkan induksi gen biosintetik etilen dan, akibatnya, produksi etilen dengan cara spesifik jaringan. Produksi etilen meningkat secara drastis 8 jam setelah penyerbukan dan terus meningkat selama 26-30 jam lebih lanjut [I][6].

Peran etilen dalam pengembangan epidermis akar arabidopis

Akar pada arabidopis memiliki sel-sel rambut akar dalam satu atau lebih file dari sel non rambut. bagian melintang pada akar menunjukkan bahwa sel rambut terletap pada atasdinding sel antiklinal sedangkan sel non rambut terletak pada atas dinding kortikal. hal ini menunjukkan bahwa sel bagian atiklinal dan kortikal yang terpapar oleh etilen selama proses perkembangan. sensitivitas terhadap etilen ini dapat ditunjukkan pada saat akar dapat tumbuh dalam kegelapan. pertmbuhan pada rambut akar bisa terhambatkarena adanya AVG dan $\mathrm{Ag}^{2+}$ sehingga masih membutuhkan bantuan etilena untuk membentuk sel rambut.sel sel rambut ektopik yang 

P-ISSN: I4I2-I395; e-ISSN: 2355-3529

tumbuh karena adanya AVG lebih sensitif terhadap adanya etilen dari pada sel-sel yang menutup pada dinding antiklinal.

\section{METODE PENELITIAN}

Bahan tanaman: Tanaman Catasetum fimbriatum (Morren) Lindl. (Orchidaceae) (klon CFCl) diperoleh dengan teknik micropropagation shoot etiolated [3]. Segmen nodal dari pucuk etiolasi yang panjangnya sekitar $5 \mathrm{~mm}$ diinkubasi dalam gelap dan dalam cahaya dalam medium yang dimodifikasi dengan mengganti $\mathrm{Fe}_{2}\left(\mathrm{C}_{4} \mathrm{H}_{4} \mathrm{HAI}_{6}\right)$ untuk Fe-EDTA, dan ditambah dengan mikronutrien dari [3]. PH medium disesuaikan menjadi 5,8 sebelum menambahkan 0,2\% Phytagel, dan diautoklaf selama 15 menit pada 120HaiAsam 2-kloroetil-fosfonat (CEPA), senyawa pelepas etilena, difilter disterilkan dengan Millex $\mathrm{HV}(0,45)$ $\mu \mathrm{m})$ dan ditambahkan ke media pada dua konsentrasi $(4,20 \mu M$ dan 13,84 $\mu M)$ ketika suhunya mencapai 40HaiC. Eksperimen awal menunjukkan bahwa konsentrasi ini, masingmasing, paling tepat untuk mengevaluasi pengaruh etilen terhadap kadar hormon endogen, dan efeknya pada pola pertumbuhan dan perkembangan [3].

Setiap perlakuan terdiri dari tiga labu Erlenmeyer $(250 \mathrm{~mL})$ yang mengandung $80 \mathrm{~mL}$ media kultur dan 15 segmen nodal, dan ditutup dengan sumbat karet. Kultur diinkubasi pada $25 \pm$ $2 \mathrm{HaiC}$ dalam gelap atau di bawah fotoperiode 16 jam menggunakan lampu neon pada $40 \mu \mathrm{mol} \mathrm{m}$ -

2 s-luntuk 60 d. Metode ini digunakan untuk mengevaluasi efek etilen eksogen dan kuantifikasi hormon pada tunas dan akar [3]. Untuk penentuan pertumbuhan tunas, hanya ukuran pseudobulb yang diukur, dan daun

tidak dipertimbangkan. Analisis pertumbuhan dilakukan dengan 45 tanaman (tiga labu dengan masing-masing 15 tanaman) dan nilai dinyatakan sebagai rata- rata \pm kesalahan standar.

Penentuan kadar hormon endogen

Tingkat endogen IAA, ABA, zeatin, zeatin riboside, isopentenyladenine (IP), dan isopentenyladenosine diukur menggunakan I g jaringan segar. Metode imunoenzimatik dilakukan dengan beberapa modifikasi Metode ini memungkinkan penentuan tiga kelas hormonal dalam ekstrak yang sama. Jaringan bubuk beku-kering diaduk dan diekstraksi dalam $10 \mathrm{~mL}$ dingin $80 \%$ ( $\mathrm{v} /$ v) metanol berair yang mengandung butylhydroxytoluene $(0,18 \mathrm{mM})$ sebagai antioksidan, selama 60 jam pada 4HaiC dalam kegelapan. Standar berlabel radio yang di-tritiated, Amersham. Laboratorium Isotop dengan aktivitas spesifik 999 GBq mmol-I, 2,37 TBq mmol-I, dan 0,6 TBq mmolI, masing-masing) ditambahkan ke sampel untuk estimasi pemulihan setelah pemurnian. Ekstrak metanol disaring dan kemudian melewati kartrid Sep-Pak CI8. Setelah filtrasi, eluat dikurangi menjadi kekeringan dalam konsentrator Speed Vac (HETO CT II0) dan residu dilarutkan kembali dalam 500 $\mathrm{mL}$ air asam (1000 mL air + $100 \mu \mathrm{L}$ asam format, $\mathrm{pH}$ 3.0). Hormon- hormon tersebut kemudian dipisahkan lebih dari 80 menit oleh HPLC, yang terdiri dari dua pompa, pengontrol gradien 746, penginjeksi manual U6K, detektor penyerap UV 486 dan integrator 746) menggunakan fase semi preparatif fase terbalik $\mu$ Bondapack kolom $19 \times 300 \mathrm{~mm}$, dengan laju aliran $5 \mathrm{~mL}$ minIdengan gradien air metanol / asam. Gradien terdiri dari $5 \%$ metanol pada waktu nol, 30\% metanol pada 15 menit, 45\% metanol pada 30 menit, dan 50\% metanol pada 50 menit. Dalam semua kasus, air asam ditambahkan ke metanol untuk mendapatkan nilai $100 \%$ yang sesuai.

\section{HASIL DAN DISKUSI}

Dari hasil perlakuan gelap sangat mengubah karakteristik umum tanaman C. fimbriatum. Misalnya, tanaman yang tumbuh di bawah cahaya selama 60 hari membentuk batang pendek normal, akar dan daun, sedangkan individu yang diinkubasi gelap berasal batang panjang berwarna (lebih tinggi 2,84 kali lipat), dengan penghambatan total pembentukan akar, dan peningkatan massa kering 
Handri Rama Pradani. Peran Ethylane Dalam Pertumbuhan Dan Pengembangan Tanaman.

Tumbuhan yang diinkubasi dengan cahaya yang diolah dengan etilena menyebabkan pengurangan panjang tunas yang teriiolasi (lebih pendek 2,84 kali) dan pertumbuhan daun dan, sampai batas tertentu, pertumbuhan akar terbelakang (lebih pendek I,72 $\mathrm{cm})$. Mengenai penghambatan daun, fenotip sangat mirip dengan $C$. fimbriatum sering diamati dengan genera dekat lainnya ketika diinkubasi dalam labu berventilasi buruk, mungkin karena akumulasi etilen. Efek penghambatan yang ditandai dari etilen terhadap pertumbuhan daun dalam kondisi cahaya (Gambar I) dan tingkat yang sama dari sitokinin yang diukur dalam tanaman yang ditumbuhkan dengan perlakuan etilen dan tanpa perlakuan memungkinkan kita untuk berhipotesis bahwa etilen entah bagaimana secara langsung terlibat dalam proses daun penghambatan pertumbuhan dalam kondisi cahaya.

\section{KESIMPULAN}

Etilen merupakan gas pertumbuhan pada tanaman.. Etilen berasal dari asam amino dan metonin. Metionin diubah menjadi asam Iaminocyclopropane- I-karboksilat . Etilen merupakan penginduksi kuat dari pembungaan dalam geofit, tanaman dengan organ perennating bawah tanah, seperti umbi-umbian Dari penelitian yang telah banyak dilakukan, menyatakan bahwa etilen mempunyai peran penting dalam pertumbuhan dan perkembangan tanaman. Dimulai dari bentuk tanaman, pertumbuhan batang, proses layunya bunga dan pertumbuhan akar. Inovasi terbaru yang dilakukan oleh peneliti yaitu seperti biosintesis etilen untuk meningkatkan mutu tanaman dan dapat juga digunakan untuk memprediksi berapa umur dari tanam tersebut. Keadaan terang, gelap dan etilena menunjukkan efek yang berbeda pada semua parameter yang dianalisis dalam tunas dan akar. Dalam kegelapan, pertumbuhan pucuk yang intens bertepatan dengan akumulasi sitokinin endogen yang signifikan, yang sebenarnya dua kali lebih besar dari cahaya.

\section{REFERENSI}

[1] Dolan, Liam. 1997.The Role of ethylene in the development of plant form. Journal of Experimental Botany.
48(307), 201-210.

[2] E. Q. P. Tavares, A. Grandis, C. G. Lembke, G. M. Souza, E. Purgatto, A. P. De Souza and

M. S. Buckeridge. 2017. Roles of auxin and ethylene in aerenchyma formation in sugarcane roots. Plant Signaling \& Behavior. I3(3)

[3] Suzuki, M Rogerio and Giberto B. Kerbauy. 2006. Effects of light and ethylene on endogenus hormones and development Cataseum fiimbriatum (Orchidaceae). Research Article.

[4] Dubois, Marieke, Lisa Van den Broeck and Dirk Inze. 2018. The Pivotal Role of Ethylene in Plant Growth. Trends in Plant Science.23(4).

[5] Centre, John Innes Colney and Norwich NR4 7UH, UK. 1997. The role of ethylene in the development of plant form. Journal of Experimental Botany. 48(307), 20I-210.

[6] Schaller, G Eric. 20I2. Ethylene and the regulation of plant development. Schaller BMC Biology. I0(9)

[7] Salazar, Carolina, Cristián Hernández and María Teresa Pinol. 20I5. Plant water stress: Associations between ethylene and abscisic acid response. Chilean Journal of Agricultural Research, 7I-79.

[8] Vasevaa, Irina Ivanova, Enas Qudeimata, Thomas Potuschakb, Yunlong Dua, Pascal Genschikb, Filip Vandenbusschea and Dominique Van Der Straetena. 2017. PNAS. II5(I7).

[9] Iqbal, Noushina, Nafees A. Khan, Antonio Ferrante, Alice Trivellini, Alessandra Francini and M. I. R. Khan. 2017. Ethylene Role in Plant Growth, Development and Senescene: Intercation with Other Phytohormones. Frontires in Plant Science. 8(475).

[10] Khan, Nafees A., M. I. R. Khan, Antonio Ferrante and Peter Poor. 2017. Editorial: Ethylene: A Key Regulatory Molecule in Plants. Frontires in Plant Science. 8(I782). 
[11] Zhang, Baogang, Haifeng Liul, Xinhua

Ding2, Jiajia Qiu I, Min Zhang and Zhaohui Chu. 2018. Arabidopsis thaliana ACS8 plays a crucial role in the early biosynthesis of ethylene elicited by Cu2+ ions. Journal of Cell Science. 10(1242).

[12] Gray, William M. 2004. Hormonal Regulation of Plant Growth and Development. PLoS Biology. 2(9), I270-1273.

[13] Wang, Kevin L.-C., Hai i,and Joseph R. Ecker. 2002. Ethylene Biosynthesis and Signaling Networks. The Plant Cell.

[14] Lin, Zhefang, Silin Zhong and Don Grierson. 2009. Recent advances in ethylene research. Journal of experimental Botany. 60(12), 33 I I-3336.

[15] Kumar, Vinod, Giridhar Parvatam and Gokare Aswathanarayana

Ravishankar. 2006. Electronic of Journal of Biotecnoogy. 12(2).

[16] Khan, Nafees A and M. Iqbal R. Khan. 2014. The Ethylene: From Senescence Hormone to Key Player in Plant Metabolism. Journal of Plant Biochemistry \& Physiology.2(2) 